\title{
Biological mosquito control is affected by alternative prey
}

Ram Kumar ${ }^{1,2,3}$, Priyanesh Muhid ${ }^{4}$, Hans-Uwe Dahms ${ }^{5}$, Jaigopal Sharma ${ }^{6}$ and Jiang-Shiou Hwang ${ }^{2^{*}}$

\begin{abstract}
Background: Mosquitofish were introduced to several countries of the tropics and subtropics as biological agents for the control of mosquito larvae. Meanwhile, they became a threat to native communities and fish worldwide, similar to other invasive species through resource competition, overexploitation, or habitat alteration. We investigated prey selectivity patterns of Gambusia affinis (mosquitofish) preying on larvae of the two Indian major carps (Catla catla and Labeo rohita) in the presence of varied proportions of alternative prey (rotifers, cladocerans, chironomid and mosquito larvae) under laboratory conditions.

Results: The patterns of prey selectivity in mosquitofish were influenced by the presence of alternative prey and their relative abundance in the environment. Carp larvae, when present in equal proportions, were randomly selected by mosquitofish, however, positively selected when present in higher proportions. In the presence of Hexarthra mira, Daphnia similoides or the mosquito larval instar-IV as an alternative prey, the mosquitofish preferred fish larvae regardless of prey proportions. In the medium where either mosquito larval instar-I or chironomid larvae were given as alternative prey, the mosquitofish either rejected or randomly selected the carp larvae. Given a multispecies prey combination, mosquitofish primarily selected the larvae of $L$. rohita and mosquito larval instar-I. We also found a prey switching ability of mosquitofish in relation to varying abundances of prey species in the environment.

Conclusions: The present results suggest that mosquito immatures are not the preferred food of mosquitofish when fish larvae are present in their natural habitats. Since mosquitofish and carp larvae have overlapping natural habitats and prey preferences are the invasive mosquitofish may have a substantial impact on native communities of invertebrates and fish. This way, they are equally important for extensive fisheries and conservation management.
\end{abstract}

Keywords: Invasive fish; Conservation management; Optimal foraging; Prey selection; Prey switching; Aquaculture

\section{Background}

Two species of mosquitofish, Gambusia affinis (Baird and Girard 1853) and Gambusia holbrooki (Girard 1859), have become examples of invasive species globally with negative impacts on native communities. They have invaded low-order stream sections, most of the wetlands, shallow lakes and almost all ornamental ponds in 67 tropical and subtropical countries (Duryea et al. 1996, Lever 1996, Swanson et al. 1996, Helfman 2007). In addition to competing for resources, interfering with reproduction and introducing parasites (Arthington 1991, Crowl et al. 1992, Kennard et al. 2005, Benejam et al. 2009, Hazelton and Grossman 2009), mosquitofish

\footnotetext{
* Correspondence: Jshwang@mail.ntou.edu.tw

${ }^{2}$ Institute of Marine Biology, National Taiwan Ocean University, 2 Pei Ning

Road, Keelung 202, Taiwan

Full list of author information is available at the end of the article
}

are quite aggressive and often attack fish more than twice their own body size (Wurtsbaugh et al. 1980, Howe et al. 1997). Because of their higher dispersal tendency, invasiveness (Rehage and Sih 2004) and adverse effects on native aquatic communities (Barrier and Hicks 1994, Webb and Joss 1997, Arthington and Marshall 1999, Smith et al. 2011), the database of the IUCN Invasive Species Specialist Group (www.issg.org/database) classifies mosquitofish, along with eight other species, as among the world's 100 worst invasive species ISSG, 2000; Lowe et al. 2000). Invasive exotic species may displace native species through resource competition or by overexploiting native species to the point of extinction (Dahms 2004, Clavero and García-Berthou 2005) or they may alter the habitat to such an extent that native species are no longer able to exist (Dahms 2005, Gooden et al. 2009). 
In several studies, mosquitofish have been used as a model organism to investigate pelagic trophic interactions (Hurlbert et al. 1972, Lancaster and Drenner 1990, Peck and Walton 2008), to test optimal foraging theory (Bence and Murdoch 1986, Bence 1988) or to assess genetic diversity (Vidal et al. 2010). Some dietary studies have focussed on the role that mosquitofish play in controlling insect populations (Linden and Cech 1990, Gophen et al. 1998, Hamer et al. 2002). Mosquitofish are perennially abundant in degraded hypertrophic lakes (e.g. Naini Lake, Rajghat Lake and Old Fort Lake in Delhi, India (Kak 1999), that support persistent cyanobacterial blooms (Kak 1999), an environment otherwise uninhabitable for native species. There is indication on mosquitofish-driven displacement of native species (Nagdali and Gupta 2002, Helfman et al. 2009). In India, there is a strong negative association between mosquitofish density and the Indian major carp (Nagdali and Gupta 2002, Jhingran 1991) in the natural settings. A mass-mortality event of $G$. affinis increased the density of larger-sized zooplankton and fish larvae in Lake Nainital, India (Nagdali and Gupta 2002), confirming its negative effect on native aquaculturally important fishes (Arthington 1991, Arthington and Marshall 1999, Marchetti and Moyle 2001).

Several studies have demonstrated the competitive advantage of mosquitofish over small indigenous fishes (Courtenay and Maffe 1989, Howe et al. 1997, Ivantsoff 1999) and amphibians (Vargas and De Sostoa 1996, Goodsell and Kats 1999, Komak and Crossland 2000). Other studies have described the effects of mosquitofish predation on invertebrates such as zooplankton (Margaritora 1990), odonate larvae (Englund 1999) and fairy shrimp (Leyse et al. 2004, Sornsupharp et al. 2013a, b). Despite being generalistic feeders (Rehage et al. 2005), mosquitofish exhibit strong prey selection in an environment with multiple prey types (Hurlbert and Mulla 1981, García-Berthou 1999, Kumar et al. 2008). They are able to attack a variety of prey, and their preferences are determined by several factors including prey size, morphology, biomass (Wurtsbaugh et al. 1980), transparency, relative abundance of prey in the environment (Rao and Kumar 2002, Kumar et al. 2012) and the swimming behaviour of prey (Linden and Cech 1990, Swanson et al. 1996, Alcaraz et al. 2008). This selective predation has a significant effect on the structure and dynamics of freshwater ecosystems (Kennard et al. 2005, Rao and Kumar 2002, Kumar et al. 2008), as the less preferred prey populations obtain an environment free of competition (Peck and Walton 2008, Lee et al. 2010).

Although mosquitofish have often been released in highly disturbed or artificial habitats as biocontrol agents of mosquito immatures, they have the potential to spread into pristine water bodies (Courtenay and Maffe
1989), where they can severely impact native fishes (Howe et al. 1997), amphibians (Webb and Joss 1997, Goodsell and Kats 1999) and invertebrates (Leyse et al. 2004). In a comparative study of G. holbrooki and a common native species in eastern Australia, the Pacific Blue-eye, Pseudomugil signifier Kner, it was suggested that the native fish $P$. signifier is a potential effective predator of mosquito larvae. In contrast, mosquitofish becomes a threat to native fishes that share similar habitats. This is particularly due to their eco-physiological advantages related to fast growth, early maturity, viviparity and their voracious appetite (Vargas and de Sostoa 1996).

Therefore, it is relevant to elucidate the preference of mosquitofish for the native fish communities from a wide spectrum of natural prey species (Olden et al. 2010). Relatively few studies have analysed the dietary patterns of mosquitofish (Crivelli and Boy 1987, Mansfield and McArdle 1998, García-Berthou 1999) using co-occurring fish larvae and an array of different co-occurring prey types under controlled conditions.

On the Indian subcontinent, the two commercially and aquaculturally important carp species Catla catla (Hamilton 1822) and Labeo rohita (Hamilton 1822) often co-occur with introduced mosquitofish. These two major carps are native to Indian freshwaters and are extensively used in fish-culture in both lentic and lotic waters (Jhingran 1991, Rao 2003). Due to the invasive nature of mosquitofish and the threat that mosquitofish provide for the indigenous fauna, it has become necessary to evaluate their predation potential on carp larvae. The optimal foraging model (Werner and Hall 1974, Krebs and Kacelnik 1991) predicts that a predator positively selects more profitable prey based on the energy spent in searching, encountering, attacking, capturing and ingesting, compared to the energy gained from digesting other prey (Kumar and Rao 2003, Kumar et al. 2008). Therefore, the availability of less-profitable prey should not influence the predators' decision to select more profitable prey. Hence, with an increasing abundance of profitable prey, the predator's preference should switch from random selection to positive selection (Oaten and Murdoch 1975, Akre and Johnson 1979, Kiørboe et al. 1996). The ability of a predator to switch from one prey species to another depending on their relative abundance saves energy spent in searching for less abundant prey. This is because searching is an adaptive behaviour that not only allows the predator to maximise its net energy intake but may also have a stabilising effect on the prey population (Oaten and Murdoch 1975, Kiørboe et al. 1996). Carp larvae (body length: $3.5-5 \mathrm{~mm}$ ) have a higher biomass than zooplankton and an inefficient escape response, which makes them more vulnerable to predation. Thus, this study compared the 
foraging preferences of mosquitofish between fish larvae and a series of invertebrate prey and examined the effects of variations in the relative abundance of alternative prey on fish larval preferences.

Here we pursue our hypotheses that (I) mosquitofish positively selects carp larvae over alternative invertebrate prey, and (II) mosquitofish preference for carp larvae depends on the relative abundance of alternative prey in the environment. To test these hypotheses, we evaluated quantitatively the consumption of fish larvae by the mosquitofish G. affinis (Baird and Girard, 1854), in the presence of varied proportions of alternative prey such as rotifers, cladocerans and dipteran (culicid and chironomid) larvae.

\section{Methods}

\section{Collection, culture and preparation of experimental animals}

All experimental animals, except chironomid larvae, used in this study were collected in the field prior to the experiment and cultured in the laboratory. Table 1 lists the experimental animals and their characteristics. Individuals of each prey species were used only once in an experiment. The predators used in the experiments were exposed to all prey species before testing, because they were cultured using combinations of the same prey species (fish larvae were used only occasionally) as food.

\section{Predator}

Similarly sized female mosquitofish (G. affinis) were collected with a fish net from an experimental pond in the botanical garden of Sri Guru Tegh, Bahadur Khalsa College, University of Delhi, India. All fish were immediately brought to the laboratory, where they were acclimated before the experiments. Until the experiment began, the fish were maintained in 5 stock aquaria of $15 \mathrm{~L}$ each, and provided with natural macrophytes collected from the same pond. All aquaria were cleaned, and the water was changed once a week. Each aquarium contained about 35-40 fish of similar size to be acclimated. A 14-h L:10-h D photoperiod was maintained at ambient room temperature. Mosquitofish were fed with a mixture of zooplankton, mosquito larvae and chironomid larvae. Mosquitofish individuals were used only once in feeding trials. Throughout the experimental period of 12 days, in total 130 individual fish were used for the experiments.

\section{Prey}

The experiments in this study involved representative species that were consumed by the predator (Garcia-Berthou 1999, Kumar et al. 2008) and commonly co-occur with mosquitofish in temporary waters, ornamental ponds, pools, lakes, etc. in tropical environments. Before mosquitofish were captured, zooplankton samples were collected by filtering 50-60 L pond water through a 53$\mu \mathrm{m}$ mesh. The rotifers Hexarthra mira (Hudson 1871) and Asplanchna intermedia (Hudson 1886) and the cladoceran Ceriodaphnia cornuta (Sars 1885) were isolated from zooplankton samples that were collected from the same pond as the mosquitofish (see also Chullasorn et al. 2009). However, the larger cladoceran Daphnia similoides

Table 1 Body sizes (mean $\pm S E, n=20$ ) and dry mass of prey species used in the experiment

\begin{tabular}{|c|c|c|c|c|}
\hline Group & Species & $\begin{array}{l}\text { Length } \\
(\mu \mathrm{m})\end{array}$ & Dry mass $(\mu \mathrm{g})$ & Micro-distribution and seasonality \\
\hline \multirow[t]{2}{*}{ Rotifera } & $\begin{array}{l}\text { Hexarthra mira } \\
\text { (Hudson, 1871) }\end{array}$ & $186 \pm 14.60$ & 0.08 & $\begin{array}{l}\text { Planktonic; throughout the water column; throughout the } \\
\text { year with highest abundance in summer }\end{array}$ \\
\hline & $\begin{array}{l}\text { Asplanchna intermedia } \\
\text { (Hudson, 1886) }\end{array}$ & $986 \pm 68.90$ & 1.86 & $\begin{array}{l}\text { Planktonic; throughout the water column; abundant in lake } \\
\text { plankton during summer }\end{array}$ \\
\hline \multirow[t]{2}{*}{ Cladocera } & $\begin{array}{l}\text { Ceriodaphnia cornuta } \\
\text { (Sars, 1885) }\end{array}$ & $526 \pm 16.87$ & 2.6 & Planktonic; throughout the water column; perennially abundant \\
\hline & $\begin{array}{l}\text { Daphnia similoides } \\
\text { (Hudec, 1991) }\end{array}$ & $1961 \pm 34.50$ & 27.2 & $\begin{array}{l}\text { Planktonic; throughout the water column; occurrence } \\
\text { from fall to spring with a peak during winter }\end{array}$ \\
\hline \multirow[t]{3}{*}{ Insecta } & $\begin{array}{l}\text { Anopheles stephensi } \\
\text { (Liston, 1901) larvae } \\
\text { instar-I-II }\end{array}$ & $736 \pm 14.50$ & 4.48 & Water surface; most from summer to fall \\
\hline & $\begin{array}{l}\text { A. stephensi larvae } \\
\text { instar-IV }\end{array}$ & $1896 \pm 82.00$ & 185 & Water surface; most abundant from summer to fall \\
\hline & Chironomus larvae & $3280 \pm 185.54$ & 240 & Littoral and benthic \\
\hline \multirow[t]{2}{*}{$\begin{array}{l}\text { Pisces: Cyprinidae } \\
\text { (prey) }\end{array}$} & $\begin{array}{l}\text { Catla catla } \\
\text { (Hamilton, 1822) }\end{array}$ & $4624 \pm 219.00$ & 385 & Benthopelagic in fresh to brackish water; spring and fall \\
\hline & $\begin{array}{l}\text { Labeo rohita } \\
\text { (Hamilton, 1822) }\end{array}$ & $3410 \pm 246.04$ & 310 & Throughout the water column \\
\hline $\begin{array}{l}\text { Pisces: Poeciliidae } \\
\text { (predator) }\end{array}$ & $\begin{array}{l}\text { Gambusia affinis } \\
\text { (Baird and Girard, 1854) }\end{array}$ & $4723 \pm 458.60$ & - & $\begin{array}{l}\text { Throughout the water column; littoral, higher density in surface } \\
\text { waters; perennial, more abundant from April to September }\end{array}$ \\
\hline
\end{tabular}


(Hudec 1991) was collected from an ornamental pond with a lower density of mosquitofish. The fieldcollected animals were slowly acclimated to autoclaved tap water by progressively increasing the proportion of autoclaved tap water to the filtered pond water. The cultures of the rotifer $H$. mira and both cladoceran species were expanded and maintained in autoclaved tap water, using the green alga Chlorella vulgaris Beijerinck 1890 at a density of $2-3.5 \times 10^{6} \mathrm{ml}$ as food. The rotifer Brachionus calyciflorus Pallas 1766 was used as food for the culture of the predatory rotifer $A$. intermedia. Polymorphism was observed in the A. intermedia culture. Although saccate, cruciform and campanulate morphs appeared in the laboratory cultures, only the campanulate morphs were used for the experiments (see Dahms et al. 2011a, Hwang et al. 2013).

The larvae of the mosquito Anopheles stephensi Liston 1901 were obtained from a laboratory culture. Larval cultures were maintained in a separate room at optimal, constant conditions (temperature $25 \pm 2{ }^{\circ} \mathrm{C}$, relative humidity $70 \pm 5 \%$, photoperiod $14 \mathrm{~h} \mathrm{L:10} \mathrm{h} \mathrm{D).}$ Mosquito eggs collected from the cage were placed in enamel trays containing dechlorinated water for hatching. A standard diet consisting of yeast extract and finely ground dog biscuits (2:3) was added to this tray to feed the mosquito larvae. Chironomus larvae were collected from outdoor concrete tubs as required. The larvae of C. catla and L. rohita were obtained from the aquaculture laboratory of the Department of Zoology, University of Delhi.

For all cultures and experiments, room temperature was maintained at $25 \pm 2{ }^{\circ} \mathrm{C}$. Table 1 lists the experimental animals and their characteristics.

\section{Experimental treatments}

All experiments, including five replicates for each treatment, were conducted in $30 \times 20 \mathrm{~cm}$ glass troughs containing $2 \mathrm{~L}$ autoclaved tap water. A series of short-term experiments was conducted to investigate the feeding rates (number of larvae ingested $\mathrm{h}^{-1}$ ) of the mosquitofish. The initial density (Table 2 ) for each prey type and test duration was chosen based on preliminary feeding experiments, such that at the end of each experiment a substantial number of prey remained unconsumed. The mosquitofish used in the experiments had sufficient exposure to all prey species prior to testing, since they were cultured using food in different combinations of the same prey species except fish larvae. One individual mosquitofish was transferred from the stock aquarium to the experimental trough $6 \mathrm{~h}$ prior to the experiment and deprived of food. After the fish was starved for $6 \mathrm{~h}$, prey was individually counted and placed gently in each experimental trough.
Table 2 Experimental protocols used for tests of L. rohita larval consumption and prey selection by mosquitofish

\begin{tabular}{|c|c|c|c|}
\hline Experiment & $\begin{array}{l}\text { Test } \\
\text { no. }\end{array}$ & Prey species & $\begin{array}{l}\text { Combined } \\
\text { prey density }\end{array}$ \\
\hline \multicolumn{4}{|c|}{ 1. Larval consumption rate } \\
\hline & \multirow[t]{2}{*}{1} & C. catla & 60 \\
\hline & & L. rohita & 60 \\
\hline \multicolumn{4}{|c|}{ 2. Prey selectivity: selectivity within a taxonomic group } \\
\hline $\begin{array}{l}\text { Fish larvae-fish larvae } \\
\text { choice }\end{array}$ & 2 & C. catla-L. rohita & 60 \\
\hline \multirow{2}{*}{$\begin{array}{l}\text { L. rohita } \\
\text { larvae-rotifers choice }\end{array}$} & 3 & H. mira-L. rohita & 60 \\
\hline & & A. intermedia-L. rohita & 60 \\
\hline \multirow{2}{*}{$\begin{array}{l}\text { L. rohita } \\
\text { larvae-cladocerans } \\
\text { choice }\end{array}$} & 4 & C. cornuta-L. rohita & 60 \\
\hline & & D. similoides - L. rohita & 60 \\
\hline \multirow[t]{3}{*}{$\begin{array}{l}\text { L. rohita larvae-insect } \\
\text { larvae }\end{array}$} & 5 & $\begin{array}{l}\text { A. stephensi larvae } \\
\text { instar-I-L. rohita }\end{array}$ & 60 \\
\hline & & $\begin{array}{l}\text { A. stephensi larvae } \\
\text { instar-IV—L. rohita }\end{array}$ & 60 \\
\hline & & $\begin{array}{l}\text { Chironomus larvae-L. } \\
\text { rohita }\end{array}$ & 60 \\
\hline 3. Multispecies choice & 6 & & 600 \\
\hline
\end{tabular}

\section{Experiment 1: consumption of fish larvae}

The ingestion rates of female mosquitofish preying on $C$. catla and $L$. rohita larvae were estimated. Sixty larvae of either L. rohita or C. catla were offered to previously acclimatised and starved mosquitofish in each experimental trough. The experimental design included two treatments (L. rohita + G. affinis; C. catla + G. affinis $) \times 2$ controls (L. rohita alone; C. catla alone) $\times 5$ replicates, for 20 glass troughs. Mosquitofish were removed from the experimental dishes after $3 \mathrm{~h}$ of incubation, and the number of remaining carp larvae was counted.

\section{Experiment 2: prey selection experiment}

The following prey combinations were used for the selectivity experiments: (i) C. catla - L. rohita larvae, (ii) rotifers (either H. mira or A. intermedia)-L. rohita larvae (iii) cladocerans (either D. similoides or C. cornuta) $-L$. rohita larvae (iv) mosquito larvae (either larval instarsI-II or instar-IV) - L. rohita larvae and (v) chironomid larvae-carp larvae (vi) multispecies prey combination (all abovementioned prey types in the medium). To test the null hypothesis that the preference of the mosquitofish does not change with varying proportions of alternative prey types, two prey-type choice experiments offered prey types in three different proportions $(0.33$, 0.5 and 0.67 ), providing a total of 60 prey individuals. Table 2 shows the experimental protocols for the different selectivity tests, and Table 3 shows the prey species 
Table 3 Prey species and densities used in multispecies prey selectivity tests

\begin{tabular}{lll}
\hline No. & Species & No. $2000 \mathrm{ml}^{-1}$ \\
\hline 1 & L. rohita & 8 \\
2 & C. catla & 8 \\
3 & H. mira & 200 \\
4 & A. intermedia & 60 \\
5 & C. cornuta & 50 \\
6 & D. similoides & 24 \\
7 & A. stephensi larvae instar-I & 150 \\
8 & A. stephensi larvae instar-IV & 50 \\
9 & Chironomus larvae & 50 \\
\hline
\end{tabular}

used in a multispecies choice test. The mosquitofish were allowed to feed for $1 \mathrm{~h}$. The difference between the initial and final numbers of prey in the beaker was taken as the number of prey consumed by the mosquitofish during the test period. Random sampling of some beakers did not reveal any loss of prey due to death by other causes than predation.

\section{Statistical analyses}

One-way ANOVA was used to test the differences in the consumption of C. catla and L. rohita, in terms of the number of individuals and dry mass ingested. For two prey-type choice experiments, the expected consumption (number and dry mass) of one prey species in relation to the other versus the actual prey consumption was calculated for each condition. The differences between the actual and expected prey consumption for three proportions were analysed with two-way ANOVA for both of the prey types in two prey choice tests. Nonparametric Mann-Whitney rank tests (Mann and Whitney 1947) were used to determine the differences between expected and observed values of number and dry mass ingested at particular proportions of particular prey types, depending on the two-way ANOVA results (see also Tseng et al. 2008, Kim et al. 2013a, b). The difference between the expected and actual prey consumption for each prey type in a multiple prey choice test was analysed with repeated one-way ANOVA. Prey selectivity was calculated using Manly's selectivity index $\left(\alpha_{i}\right)$ (Manly 1974), modified for a situation in which the predator consumes a substantial portion of the available prey, and hence, prey numbers in the medium decline with time, similar to our experiments. The modified formula (Chesson 1983) is:

$$
\alpha_{i}=\frac{\ln \left(n_{i 0}-r_{i}\right) / n_{i 0}}{\sum_{j=1}^{m} \ln \left(\left(n_{i 0}-r_{i}\right) / n_{i 0}\right)}, i=1,2,3 \ldots \ldots \ldots \ldots m
$$

where $\alpha_{i}$ is Manly's $\alpha$ (preference index) for prey type I; $n_{i 0}$ is the number of items of type $i$ present at the beginning of a foraging bout; $r_{i}$ is the number of items of food type $i$ in the consumer's diet; and $m$ is the number of prey types.

Manly's $\alpha_{i}$ values range from 0 to 1 . The $\alpha_{i}$ value for non-selective feeding is 0.5 with two prey-type choice tests. The $\alpha_{i}$ value for non-selective feeding is 0.11 in a multispecies choice test with nine prey types. Index values above 0.5 ( 0.11 for multispecies prey choice tests) indicate positive selection (preference), and values below 0.5 indicate negative selection (avoidance). Deviations in selectivity index values from the value for non-selective feeding were tested for statistical significance using Hotelling's $T^{2}$ test. Differences in the number and dry mass of the two prey types consumed and the arcsine-transformed selectivity index values $\left(\alpha_{i}\right)$ among three proportions were analysed with MANOVA because the response variables were not independent (Gill 2001). MANOVA results reveal the independent variables (e.g. predators, presence of alternative prey and relative abundance of prey in the present study) that best differentiate mosquitofish preferences (Gill 2001). The actual consumption data were also subjected to a general linear model factorial univariate ANOVA, to assess the interaction of the variables (prey type $\times$ proportions) and the effects of the individual factors on fish larval consumption rates. To identify homogeneous subsets of means, the ANOVA was followed by pairwise multiple comparisons using Tukey's test. Using a general linear model (Gill 2001) and a factorial multivariate ANOVA (MANOVA) test (Gotelli and Ellison 2004), this study tested the null hypotheses that the presence of alternative prey and different relative prey proportions do not affect mosquitofish preferences for fish larvae. As Pillai's trace, Wilk's lambda and Hotelling-Lawly's trace converge to a similar $P$ value despite having differences in their degrees of freedom (Scheiner 2001), Pillai's trace was used for further interpretation because it provides the most robust test (Scheiner 2001).

Prior to use of parametric statistics, the w/s normality test was used for all data. w/s normality test requires only the sample standard deviation and the data range (Kanji, 2011). The test is based on the q statistics, which is the 'studentized' range, or the range expressed in standard deviation units. The standardised range $q=\frac{w}{s}$ was estimated, where the sample standard deviation (s) and the range $(\mathrm{w})$. The null hypothesis $H_{0}$ : prey consumption is not significantly different than normal prey consumption rate in nature. The calculated $\mathrm{q}$ values were within the range of critical values, therefore, $H_{0}$ is accepted (the data are normally distributed).

The data obtained in proportions (index values, proportion eaten etc.) were arcsine transformed prior to applying parametric statistics. The distribution of proportions is binomial, and arcsine transformation of data makes the distribution normal (Sokal and Rohlf 2012). The observed proportion $\mathrm{p}$ is changed to a new form $\theta=\sin ^{-1}(\sqrt{ } p)$. 
To test prey-switching mechanisms at all prey combinations, the observed and expected consumption was subjected to regression analyses. The null hypothesis was that the ratio of two alternative prey consumed $\left(P_{1}: P_{2}\right)$ in a given time period is constant and independent of the relative availabilities of the two prey. The formula for prey switching (Landry 1981, Kiørboe et al. 1996) calculates the proportionality constant $(C)$ formula as follows:

$$
\frac{P_{1}}{P_{2}}=C\left(N_{1} / N_{2}\right)
$$

where $N_{1}$ and $N_{2}$ represent the densities of two prey species and $P_{1}$ and $P_{2}$ are the numbers of the two prey species consumed in a given time period. Increasing the values of $C$ (proportionality constant) with increasing values of $N_{1} / N_{2}$ implies prey switching.

\section{Results}

\section{Consumption of fish larvae}

Mosquitofish ingested the larvae of both fish species and consumed L. rohita larvae at a significantly higher rate than $C$. catla larvae (one-way ANOVA; $P<0.05$, Table 4, Fig. 1). However, the differences were not statistically significant in terms of larval dry mass of the two fish species ingested (one-way ANOVA, $P=0.718$, Table 4, Fig. 1).

\section{Prey selection experiment}

Gambusia affinis ingested the larvae of native cyprinid fish in all prey combinations and proportions. However, the mosquitofish preference for the fish larvae was a function of the type and relative proportion of alternative prey. The effect of alternative prey type and the interaction of prey type and prey proportion on the consumption and preference for fish larvae were highly significant (MANOVA, $P<0.01$, Table 4 ). The effect of

Table 4 One-way ANOVA results for differences in consumption of C. catla and L. rohita by mosquitofish

\begin{tabular}{llllll}
\hline & $\begin{array}{l}\text { Sum of } \\
\text { squares }\end{array}$ & df & Mean square & $F$ value & $P$ value \\
\hline $\begin{array}{l}\text { Dry mass of fish } \\
\text { larvae consumed }\end{array}$ & & & & & \\
Between groups & $36,901.389$ & 1 & $36,901.389$ & 0.135 & 0.718 \\
Within groups & $4,359,138.889$ & 16 & $272,446.181$ & & \\
Total & $4,396,040.278$ & 17 & & & \\
Number of fish & & & & & \\
larvae consumed & & 1 & 14.222 & 7.062 & 0.017 \\
Between groups & 14.222 & 16 & 2.014 & & \\
Within groups & 32.222 & 17 & & & \\
Total & 46.444 & & & & \\
\hline
\end{tabular}

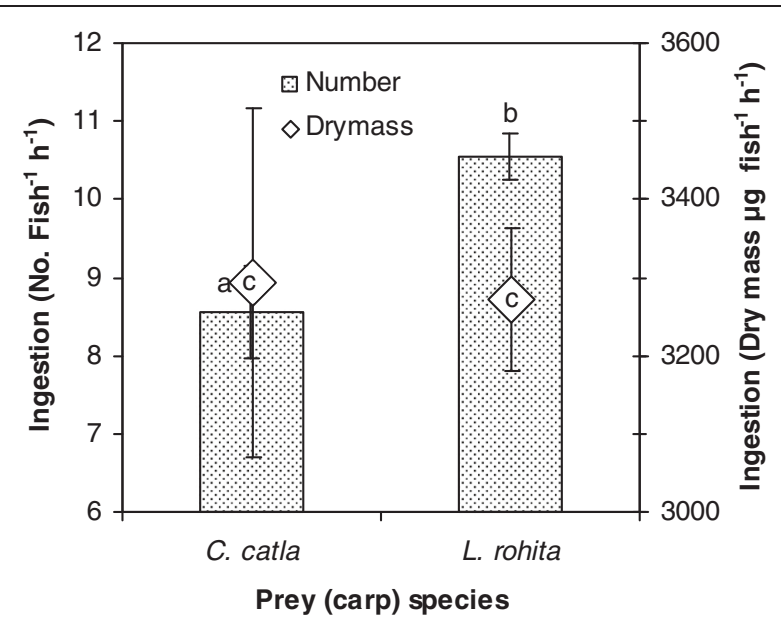

Fig. 1 Per capita and per hour ingestion (mean \pm SE) of fish larvae (C. catla and L. rohita) by mosquitofish female

prey proportion was dependent on the presence of the alternative prey type. In all test combinations, the prey preference (Manly's $\left.\alpha_{i}\right)$ was significantly correlated $\left(R^{2}=0.53\right.$ to $0.7, P<0.05$ ) with prey ingestion rates (Fig. 2).

\section{C. catla-L. rohita choice test}

When offered a combination of C. catla and L. rohita larvae, mosquitofish preferred the more abundant prey. Neither the prey type nor their interaction was significant, but the prey proportion was highly significant (MANOVA, $P<0.001$, Fig. 3, Table 5) for both, prey ingestion rate and the selectivity index $\left(\alpha_{i}\right)$ values. In either case, the number and dry mass of fish larval prey ingested by mosquitofish were significantly less (oneway ANOVA, $P<0.01$, Fig. 3$)$ than the expected value at the lowest prey proportion (0.33). The number of ingested $L$. rohita was significantly higher $(P<0.05)$ at higher prey proportion, but the ingested dry mass of $L$. rohita did not differ significantly from the expected value. The number and dry mass of either ingested fish larval prey did not differ significantly from the expected value (Mann-Whitney $U$ test; Fig. 3) at equal prey proportions.

Mosquitofish showed differential selection behaviour for the two tested rotifer species. They showed a strong preference for fish larvae, regardless of their proportion against the evasive rotifer $H$. mira (Hotelling's $T^{2}$ test, $P<0.05$, Fig. 4a, Manly's $\alpha=0.78-0.96)$. The selectivity index value was significant (MANOVA, $P<0.001$, Fig. 4a) for prey type, but neither for proportion nor for interaction $(P=0.16)$. The ingestion of $L$. rohita larvae was significantly higher than the expected value (twoway ANOVA, $P<0.001$, Fig. 4 a). However, the dry mass of ingested fish larvae did not differ significantly from the expected value, regardless of its relative proportion in the medium $(P>0.9)$. In terms of dry mass, the 


$$
\begin{array}{cc}
y=0.057 x+0.262 & y=0.0883 x+0.0707 \\
R^{2}=0.5317 \text { With C. catla } & R^{2}=0.7979 \text { With rotifers } \\
y=0.0645 x+0.0893 & y=0.0507 x+0.1975 \\
R^{2}=0.6 \text { With } A . \text { stephensi } & R^{2}=0.6768 \text { With Chironomus } \\
y=0.0755 x+0.1013 & \\
R^{2}=0.7598 \text { With Cladocerans }
\end{array}
$$

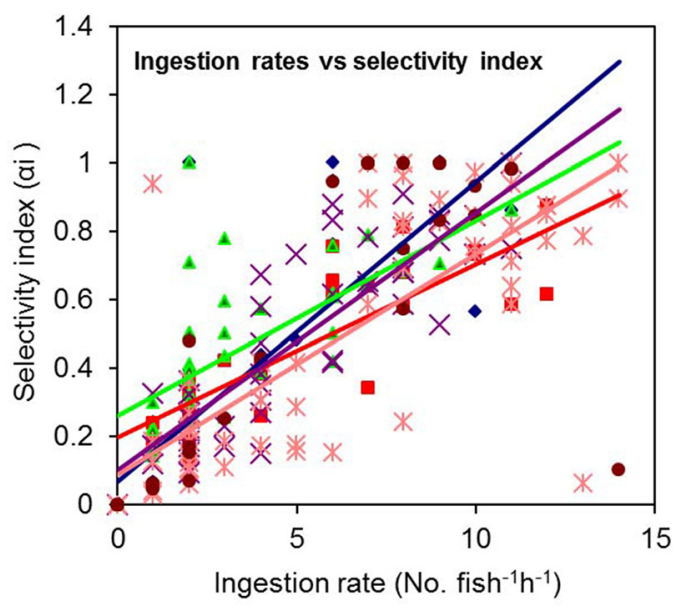

- Rotifer

- Chironomus

A Catla

$\times$ Cladocerans

A. stephensi L

- Linear (Rotifer)

_Linear (Chironomus)

Linear (Catla)

- Linear (Cladocerans)

_ Linear (A. stephensi L)

Fig. 2 Correlation between Manly's selectivity index $\left(a_{i}\right)$ and ingestion rates in mosquitofish

mosquitofish positively selected fish larvae against the larger rotifer $A$. intermedia in terms of dry mass regardless of prey proportions (Hotelling's $T^{2}$ test, $P<0.05$; Manly's $\alpha_{i}=0.76-0.92$, Fig. $\left.4 \mathrm{~b}\right)$. However, in terms of the number of ingested larvae, the fish larvae were selected positively (Hotelling's $T^{2}$ test, $P<0.05$; Manly's $\alpha_{i}=0.72-0.9$; Fig. 4b) at higher or equal proportions but were randomly selected at lower proportion. In contrast, A. intermedia was selected positively at higher proportion (0.67) (Fig. 4b) and negatively selected at equal or lower proportion when the index value was calculated with the number of ingested prey. From a combination of $L$. rohita larvae and $C$. cornuta, the mosquito fish prey preference depended on the proportion of prey in the environment (MANOVA, $P<0.001$, Fig. 5a). C. cornuta was positively selected when offered at higher proportion whereas fish larvae were positively selected when offered at higher or equal proportion (Fig. 5a).

Regardless of the prey proportion, fish larvae were positively selected (MANOVA, $P<0.001$; Hotelling's $T^{2}$ test, $P<0.001$; Manly's $\alpha=0.76$ to 0.84 ) when the larger cladoceran $D$. similoides was present as an alternative prey; whereas $D$. similoides was not selected against the fish larvae (Fig. 5b). Prey type-related differences in number and dry mass ingestion were highly significant (MANOVA, $P<0.001$, Table 5), whereas proportionrelated differences were neither significant for the dry mass (MANOVA, $P=0.188$ ) nor for the selectivity index values calculated with the ingested dry mass (MANOVA,
$P=0.483)$. The number and dry mass of ingested $D$. similoides was significantly less (two-way ANOVA, $P<$ 0.01 , Fig. $5 b)$ than the respective expected values, regardless of the relative prey proportion. In contrast, the numbers of ingested fish larvae were significantly higher (two-way ANOVA, $P<0.01$ ) than the expected value.

The mosquitofish exhibited a strong preference for instar-I stage of $A$. stephensi and negatively selected the fish larvae (Hotelling's $T^{2}$ test, $P<0.05$; Manly's $\alpha=0.14$ to 0.36 , Fig. 6a) regardless of prey proportion in the medium. Dry mass and number of A. stephensi instar-I actually ingested by the mosquitofish were significantly higher (two-way ANOVA, $P<0.001$, Fig. 6a) than the expected values at all proportions (two-way ANOVA, $P=0.052$ ). The interaction between prey type and proportion was not significant (two-way ANOVA, $P=0.557$ ). The actual dry mass of ingested $L$. rohita did not differ significantly (two-way ANOVA, $P=0.858$, Fig. 6a) from the expected value but the number of ingested $L$. rohita was significantly lower (two-way ANOVA, $P<0.001$, Fig. 6a) than the respective expected values. In contrast, mosquitofish strongly avoided (Manly's $\alpha=0.06-$ 0.18) A. stephensi instar-IV and positively selected fish larvae (Manly's $\alpha=0.82-0.94$, Fig 6b) regardless of the proportion of prey in the medium. The number and dry mass of actually ingested mosquito larvae instar-IV were significantly lower (two-way ANOVA, $P<0.001$, Fig. 6b) than the expected values regardless of prey proportions in the environment. 

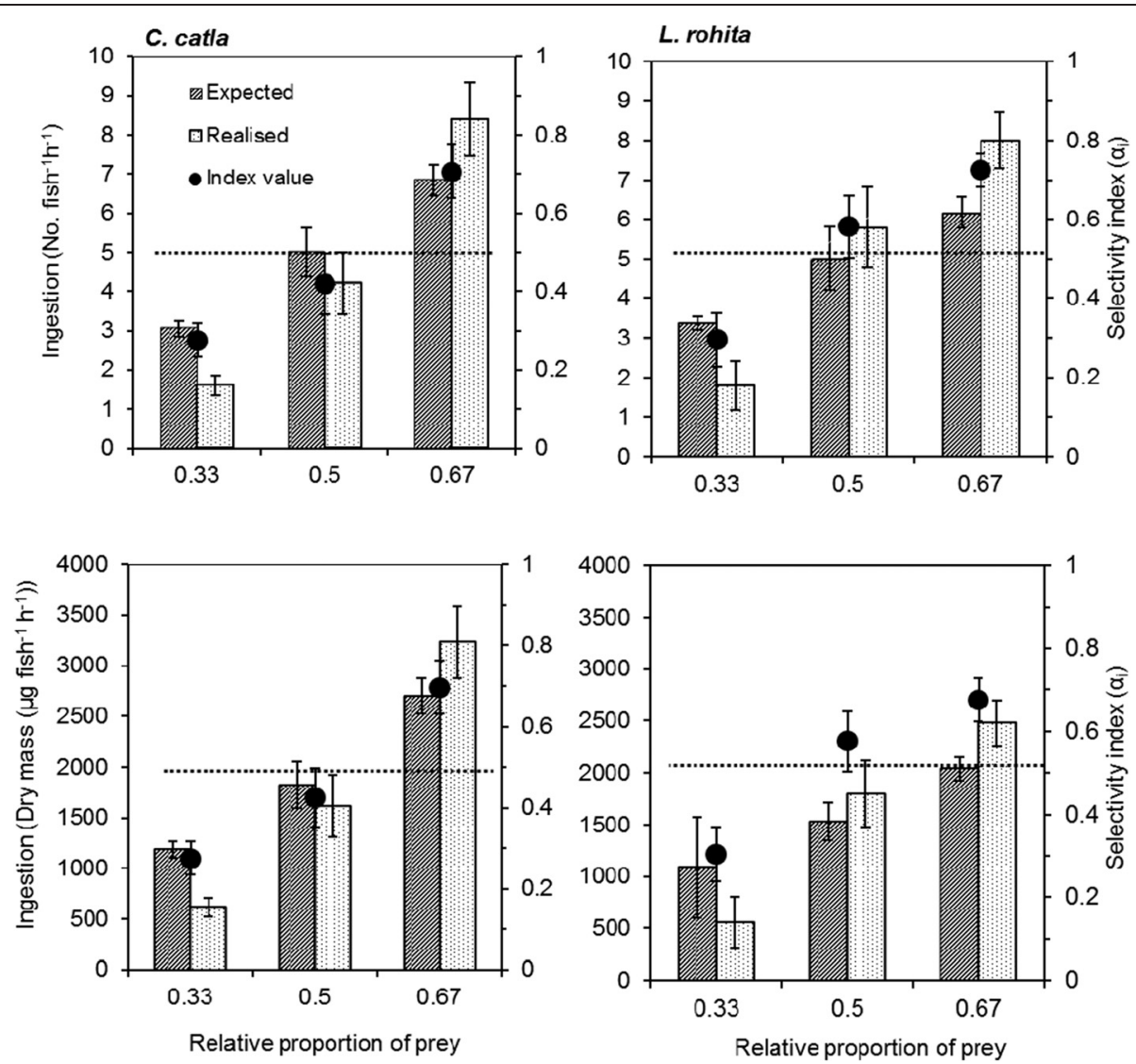

Fig. 3 Expected and observed mean ingestion rates and Manly's selectivity index $\left(a_{i}\right)$ in mosquitofish given a mixture of $C$. catla and L. rohita larvae. The dashed line in each indicates the $a_{i}$ value (secondary $Y$-axis) for non-selective feeding

The actual dry mass of ingested fish larvae did not differ significantly (two-way ANOVA, $P<0.858$, Fig. 6b) from the expected value but the number of ingested fish larvae was significantly higher (two-way ANOVA, $P<0.001$, Fig. 6b) than the expected value at a higher proportion. The prey proportion $(P<0.001)$, but not the prey type $\times$ proportion interactions were significant $(P>0.337)$.

In the fish larvae-chironomid larvae choice test, prey type-related differences in prey ingestion rates were significant for the dry mass of ingested prey $(P<0.001$; MANOVA, Table 5) and for the prey selectivity index values calculated with the number of prey (MANOVA, $P<0.001$, Table 5, Fig. 6c) consumed. Neither the number of prey $(P=0.24$; MANOVA $)$ nor the selectivity index value calculated with dry mass $(P<0.067)$ was significant. The proportion-related effects on differences in prey ingestion and selectivity index values for number and dry mass were highly significant (MANOVA, $P<0.001$,

Table 5 Results of a multivariate ANOVA (Pillai's Trace and Roy's Largest Root test) for number and dry mass of prey consumed and for selectivity index value calculated for number and dry mass of prey ingested

\begin{tabular}{|c|c|c|c|c|c|c|}
\hline Effect & & Value & $F$ value & Numerator (df) & Denominator (df) & $P$ value \\
\hline \multirow[t]{2}{*}{ Intercept } & Pillai's trace & 1.000 & $199,732.51$ & 24 & 1 & 0.002 \\
\hline & Roy's Largest Root & $4,793,580.3$ & $199,732.51$ & 24 & 1 & 0.002 \\
\hline \multirow[t]{2}{*}{ Type } & Pillai's trace & 1.000 & $84,979.222$ & 24 & 1 & 0.003 \\
\hline & Roy's Largest Root & $2,039,501.3$ & $84,979.222$ & 24 & 1 & 0.003 \\
\hline \multirow[t]{2}{*}{ Proportion } & Pillai's trace & 1.920 & 1.997 & 48 & 4 & 0.265 \\
\hline & Roy's Largest Root & $409,866.4$ & $34,155.5$ & 24 & 2 & 0 \\
\hline \multirow[t]{2}{*}{ Type $\times$ proportion } & Pillai's trace & 1.997 & 56.091 & 48 & 4 & 0.001 \\
\hline & Roy's Largest Root & $100,356.61$ & 8363.051 & 24 & 2 & 0 \\
\hline
\end{tabular}


Table 6 Between-subjects effects (MANOVA) for multispecies prey choice test

\begin{tabular}{|c|c|c|c|c|c|}
\hline Dependent variable & Type III sum of squares & df & Mean square & $F$ & $P$ value \\
\hline Number ingested & $122,520.8$ & 8 & $15,315.1$ & 26.769 & 0.000 \\
\hline Dry mass ingested & $2,764,194.5$ & 8 & $345,524.312$ & 56.952 & 0.000 \\
\hline Selectivity index value for number & 0.242 & 8 & 0.03 & 41.721 & 0.000 \\
\hline Selectivity index value for dry mass & 0.226 & 8 & 0.028 & 31.878 & 0.000 \\
\hline
\end{tabular}
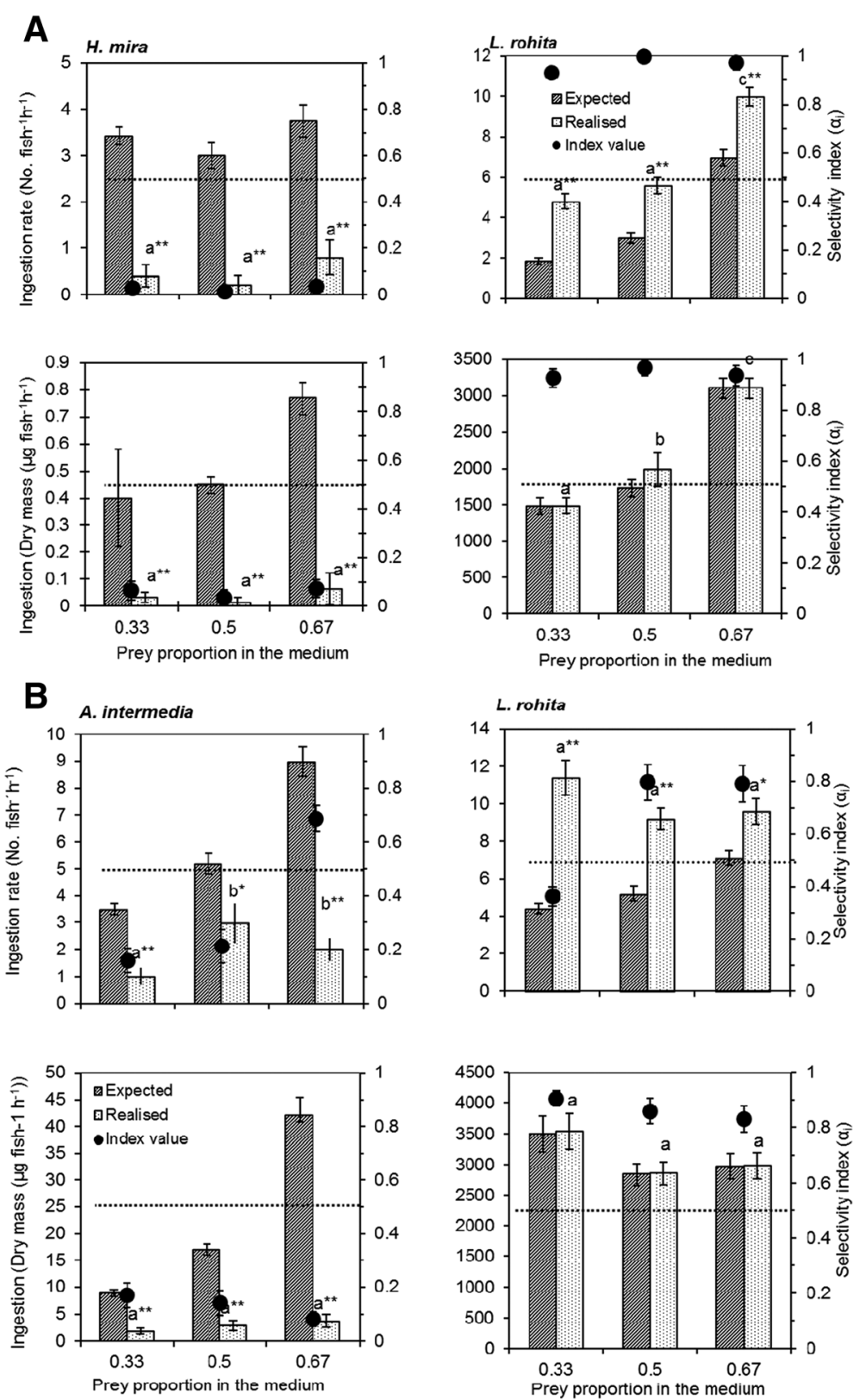

Fig. 4 Expected and observed mean ingestion rates and Manly's selectivity index $\left(a_{i}\right)$ for mosquitofish in Rotifera — L. rohita larvae choice test: a H. mira - L. rohita test combinations; $\mathbf{b}$ A. intermedia - L. rohita test combinations. The dashed line in each indicates the $a_{i}$ value (secondary Y-axis) for non-selective feeding 

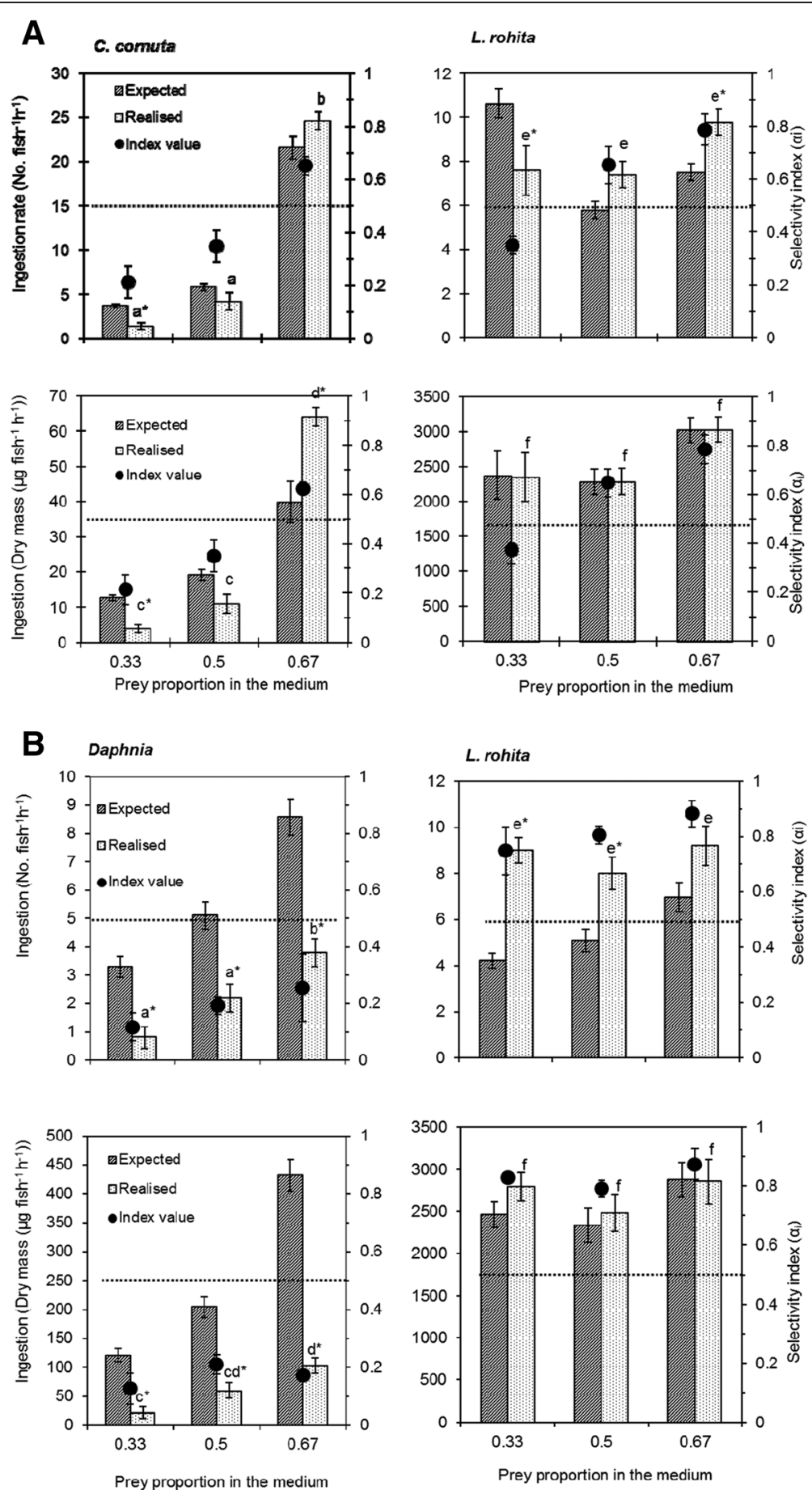

Fig. 5 Expected and observed mean ingestion rates and Manly's selectivity index $\left(a_{i}\right)$ for mosquitofish in Cladocera-L. rohita larvae choice test: a C. cornuta - L. rohita test combinations; $\mathbf{b}$ D. similoides - L. rohita test combinations. The dashed line in each indicates the $a_{i}$ value (secondary $\mathrm{Y}$-axis) for non-selective feeding

Table 5, Fig. 6c). The interaction effect between prey type and proportion was significant only for the selectivity index value calculated for the number of prey ingested. Number and dry mass of either prey type ingested were significantly lower (Mann-Whitney $U$ test, $P<0.01)$ at lower proportion, did not differ significantly at equal proportion (except the number of chironomid larvae ingested) and were significantly higher than the respective expected values at the higher prey proportion. 


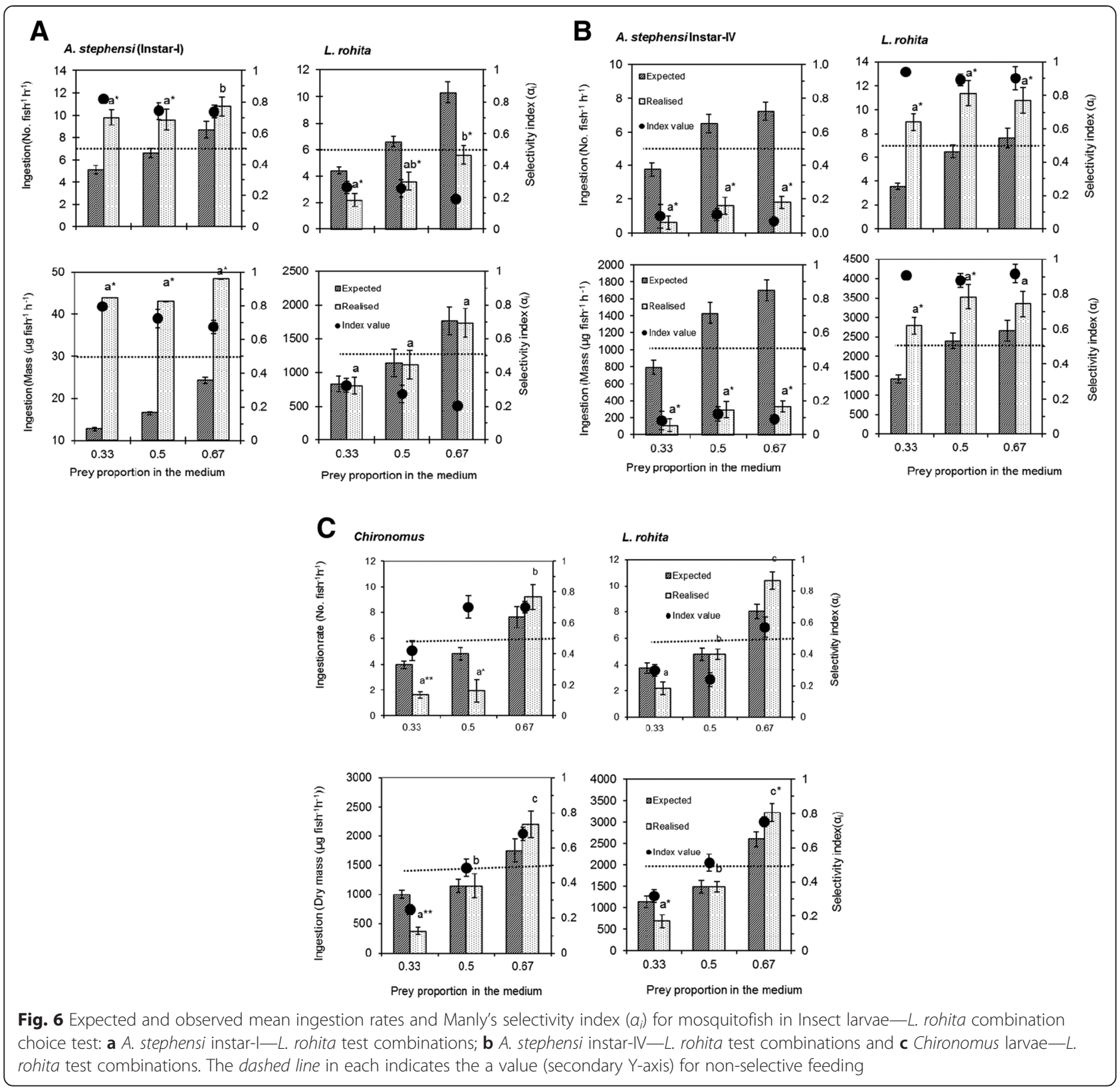

Given a choice of all nine prey types (Table 3), the mosquitofish exhibited a significant preference for the larvae of $L$. rohita (Hotelling's $T^{2}$ test, $P<0.01$; Manly's $\alpha=2.46$, Fig. 7) and the mosquito larvae-instar-I (Hotelling's $T^{2}$ test, $P<0.01$; Manly's $\alpha=2.36$, Fig. 7), strong avoidance of $D$. similoides and mosquito larvae instar-IV and random selection for the remaining prey. With respect to dry mass consumed, both the fish larvae were positively selected; $C$. cornuta, $D$. similoides, $A$. stephensi instar-I and the remaining prey types were avoided (Hotelling's $T^{2}$ test $\alpha=2.46$, Fig. 7). In terms of dry mass, the actual ingestion was significantly higher $(P<0.01$; Mann-Whitney $U$ test; MANOVA, Table 6) for larvae of both fish species, C. cornuta and A. stephensi instar-I, and was significantly lower (MannWhitney $U$ test, $P<0.01$, Fig. 8) for $H$. mira and A. stephensi instar-IV than the respective expected values.

The prey combination proportion and their interaction effects were highly significant (two-way ANOVA, $P<0.01$ ) for the total dry biomass ingested by mosquitofish. Significantly less dry mass was ingested from the mosquito larvae instar-I-L. rohita larvae combination at all three proportions (Fig. 8), and from the equal or higher proportions of the H. mira-fish larvae combination.

Finally, an analysis of our data from all eight tests with two prey types, using Landry's (1981) formula (see 

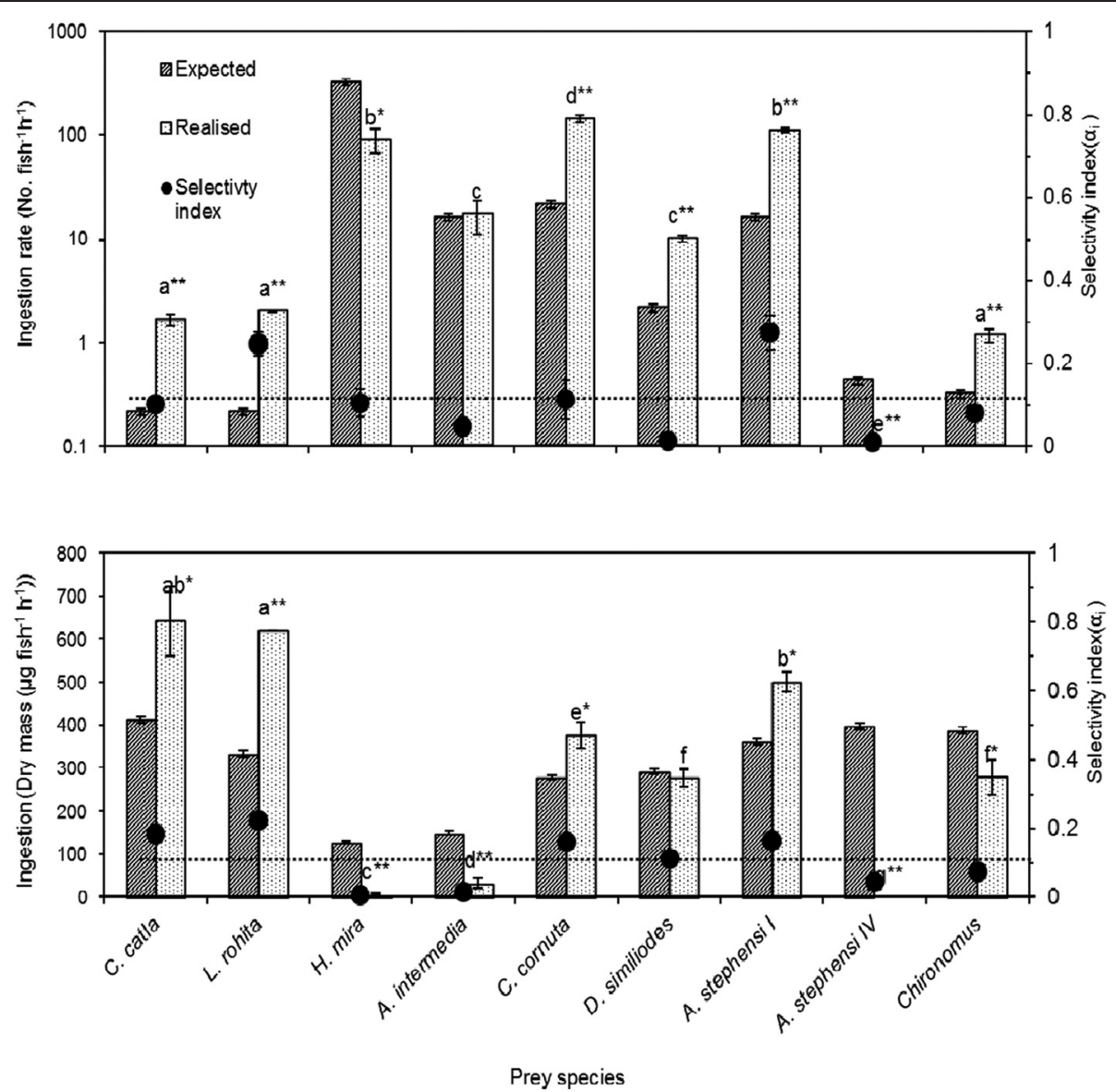

Fig. 7 Expected and observed mean ingestion rates of number (fish $\left.{ }^{-1} h^{-1}\right)$ and $d r y\left(\mu g\right.$ fish $\left.{ }^{-1} h^{-1}\right)$ biomass and Manly's selectivity index $\left(a_{i}\right)$ for mosquitofish in multispecies prey choice test. The dashed line indicates the a value (secondary Y-axis) for non-selective feeding

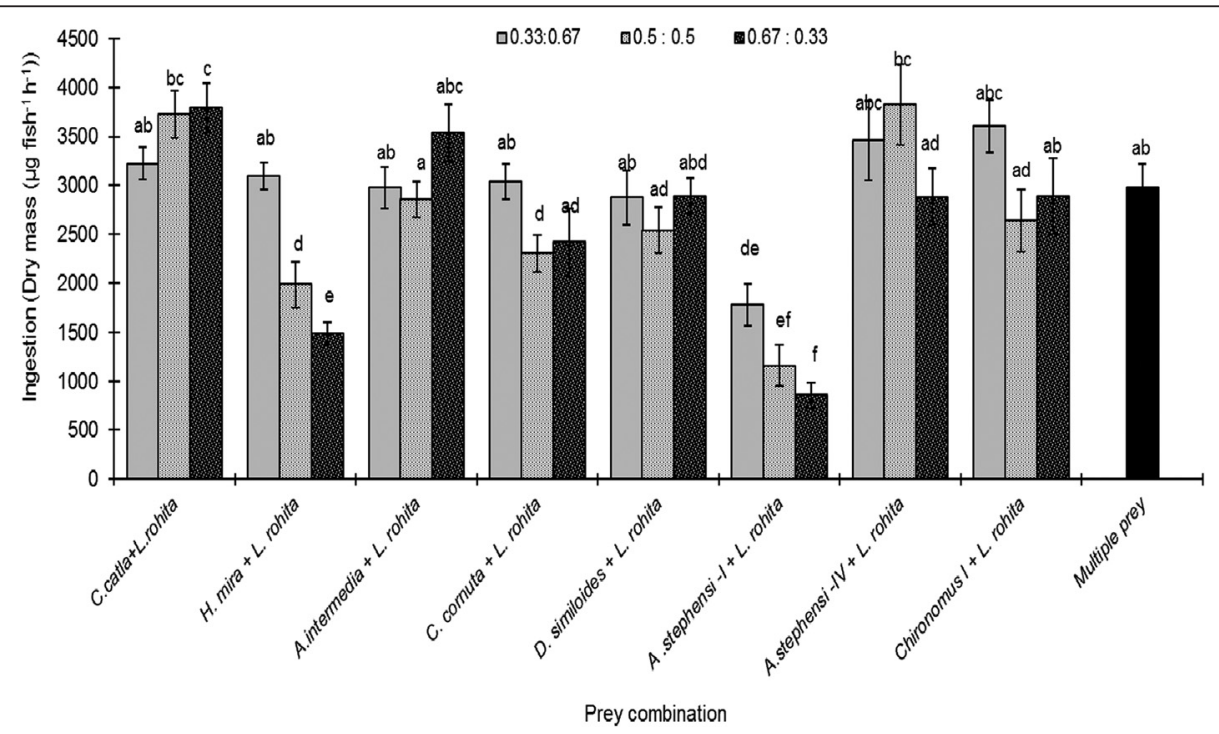

Fig. 8 Total dry mass ingestion ( $\mu \mathrm{g} I n \mathrm{~d}^{-1} \mathrm{~h}^{-1}$ ) in the mosquitofish at different prey combinations and proportions 
'Methods'), is as follows: the proportionality constant increased with increasing value of $N_{1} / N_{2}$ in C. catla $-L$. rohita $\left(R^{2}=0.54 ; P<0.01\right.$; Fig. 9), C. cornuta - L. rohita $\left(R^{2}=0.54 ; P<0.01\right)$ and Chironomus larvae $-L$. rohita combinations $\left(R^{2}=0.73 ; \quad P<0.001\right)$, which indicates switching in the prey preference of mosquitofish in relation to the relative abundance of prey in the environment (Fig. 9).

\section{Discussion}

This study demonstrated that the mosquitofish G. affinis prefers fish larvae and consumes a substantial number of fish larvae even in the presence of an alternative, naturally occurring prey. Mosquitofish consistently preferred fish larvae in all three test combinations (involving H. mira, D. similoides and A. stephensi instar-IV) across the three relative abundances tested. Mosquitofish preferred fish larvae in three test combinations when present in equal proportions and preferred fish larvae in higher proportions at all prey combinations tested, except with $A$. stephensi instar-I larvae. These results show that the vulnerability of fish larvae to mosquitofish predation depends upon the identity and the relative abundance of alternative prey. Fish larvae were consistently preferred only if an alternative prey was small rotifers, D. similoides, or larger instars of mosquito larvae. However, as recorded in Experiment I, the fish larvae were consumed readily in the absence of an alternative prey. Prey profitability varies as a function of their relative abundance and the distinctiveness of alternative prey (Rao and Kumar 2002). The size, morphology and behaviour of an alternative prey, therefore, indirectly influence the predatory removal of carp larvae from a system. Since quantitative data on the abundance of mosquitofish in natural waters are not available, we cannot extrapolate the effect of its predation on natural populations of fish larvae. Since their worldwide introduction, several studies on mosquitofish have confirmed negative effects of their predation on indigenous fish species (Courtenay and Maffe 1989, Howe et al. 1997, Ivantsoff 1999). The role of an invasive mosquitofish in shaping wetland fish assemblage structures has been well established in Australian wetlands (Macdonald et al. 2012). However, no study has been conducted on Indian wetlands. The multispecies prey choice test in this study shows the selective elimination of carp larvae by poeciliids in a natural setting. Note that the feeding data in this study do not include partially eaten or killed but only unconsumed larvae. Therefore, this study provides conservative estimates of total mortality rates. However, it is likely that Gambusia-imposed elimination of carp larvae in this study is higher than that in nature, because the prey density used here was higher than that in the field.

The prey selectivity of mosquitofish is influenced by hunger level (which was not investigated here), but more importantly by the size, shape, taste acceptability and behaviour of the prey. For instance, the laboratory experiment in this study showed that larval carp were more vulnerable to mosquitofish predation when either the evasive rotifer, $H$. mira, or the larger cladoceran, D. similoides, were also present.

The larvae of C. catla and L. rohita were similar in many respects, but differed in size. Evidently, either of these larvae was preyed upon randomly by mosquitofish if present in equal proportions. This is because preference is a function of the relative proportion of larvae in the medium. Because of their small size, rotifers are an ideal first food for the larvae of carp species (Lubzens

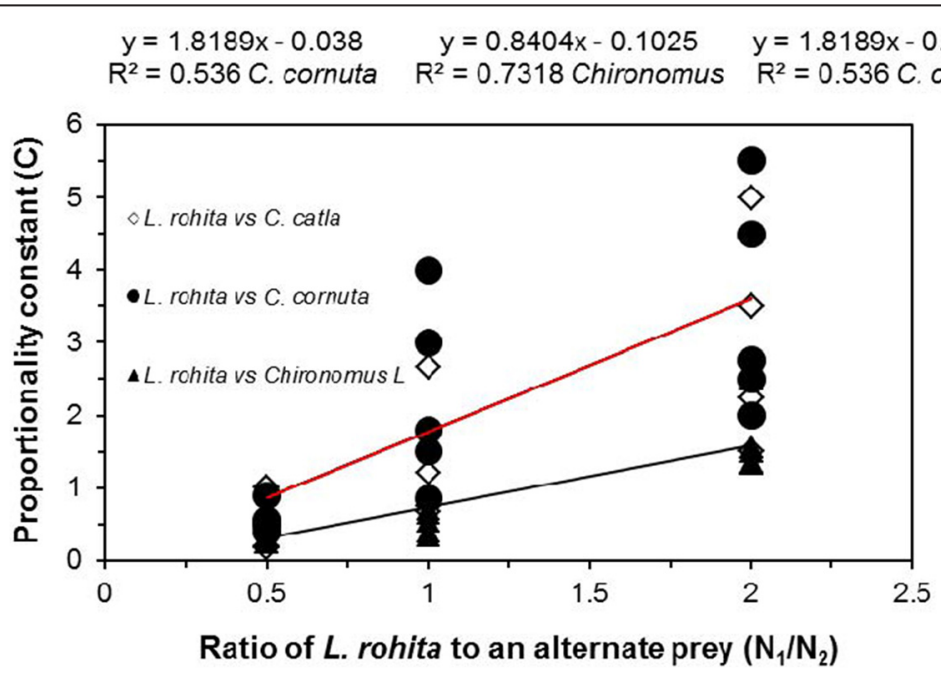

Fig. 9 Prey switching in mosquitofish, i.e. value of $C$ (proportionality constant: ratio of the proportion of prey in the diet and the initial prey proportion in the medium) in relation to the initial ratio $\left(N_{1} / N_{2}\right)$ of the two prey abundances in the medium 
et al. 1989, Kumar et al. 2012). However, if mosquitofish are present in the system, they will actively eliminate carp larvae and avoid the rotifer $H$. mira. H. mira performs evasive darting movements that reduce the risk of predation, as reported for the predatory rotifer Asplanchna (Gilbert and Williamson 1978, Iyer and Rao 1996) and the predatory copepod Mesocyclops (Williamson 1983, Kumar 2003, Rao and Kumar 2002). H. mira was the smallest alternative prey used in this study. Hence, plausible explanations for its low elimination rates would be the evasive behaviour and smaller size of this rotifer. A similar explanation was provided in an earlier study investigating the interaction between the predatory rotifer A. intermedia and H. mira (Iyer and Rao 1996). The preference of freshwater poeciliids for prey below the threshold size decreases abruptly (e.g. Werner et al. 1983, Bence 1988, Bence and Murdoch 1986). The larger rotifer, A. intermedia, are transparent and swim slowly and smoothly; both traits may reduce their conspicuousness (Gilbert and Williamson 1978, Dahms et al. 2011b). These characteristics may be responsible for the lower vulnerability of $A$. intermedia. Due to their wriggling behaviour and eye spots, carp larvae are more visually apparent to feeding mosquitofish. A. intermedia was neither preferred nor avoided when present in equal or higher proportions. The mosquitofish preference pattern was related to the relative abundance of the prey. Due to morphological, physiological and ecological constraints, fish species may not always behave according to the predictions of optimal foraging theory in selecting a particular prey type or size (Pyke 1984, Cabral and Marques 1999, Mookerji and Rao 1993, 1994).

The smaller cladoceran, C. cornuta, might be more conspicuous for mosquitofish because of its darker colour and thicker cuticle. The relatively thicker cuticle of C. cornuta protects it against predation by Mesocyclops (Matsumura-Tundisi et al. 1990, Rao and Kumar 2002, Kumar 2003). For C. cornuta, the risk of being conspicuous apparently outweighs any benefit accruing from its thicker cuticle, which may offer some protection against predation by Mesocyclops (Matsumura-Tundisi et al. 1990, Rao and Kumar 2002) but not against mosquitofish. Prey visibility and consequently the reactive distance increase with prey contrast (Rao 2003). Since nearly all zooplankton species are transparent, anything that increases their visual contrast (such as the thicker and darker cuticle of Ceriodaphnia) will ultimately make them more vulnerable to a visual predator. The negative selection of $D$. similoides against carp larvae must be interpreted with caution. Bence and Murdoch (1986) found that prey size per se is not a reliable determinant of mosquitofish preference when its diet choice includes prey species that differ in other attributes. Repeated behavioural observations of $D$. similoides under a stereomicroscope in this study showed avoidance behaviour against mosquitofish. Previous studies indicate that larger-sized $D$. similoides were not a preferred food for mosquitofish (Hurlbert and Mulla 1981, Bence and Murdoch 1986). The body size and escape behaviour of the prey are also determinant factors for the prey preference of mosquitofish: early instars of mosquito larvae were strongly selected over fish larvae. Avoidance of instar-IV mosquito larvae by the mosquitofish in the carp larvaemosquito larvae selection experiment may not be due only to a difference in size, as both the larvae (mosquito larval instar-IV and carp larvae) were comparable in size. The observed avoidance of larger instars of mosquito larvae could be attributed to their relatively thick exoskeleton and dense setation. As observed through a stereomicroscope, mosquito larvae instar-IV did not elicit an active attack response by the mosquitofish, even after an encounter. The active avoidance of carp larvae in the presence of chironomid larvae as an alternative prey further suggests that the body size of the mosquito larval instar-IV was not a causative factor in its avoidance.

Because they are larger in size and heavier in dry biomass, chironomid larvae were preferred above fish larvae when present in equal or higher proportions. However, mosquitofish preferences switched to carp larvae when larval carp were present in higher proportions. For prey that differ in frequency of encounter and ease of capture but are similar in nutritional quality, optimal foraging theory predicts switching behaviour depending on the relative abundance of prey (Bence and Murdoch 1986, Schoener 1987, Krebs and Kacelnik 1991). Many fish species are able to switch from one feeding mode to another, depending on the size and concentration of the prey (Mookerji and Rao 1993). Chironomus larvae that were preferred in our two prey choice tests were not a preferred food types in a multispecies choice test. Note that previous fish experience with prey items may also have affected the preferences of prey. Mosquitofish were thoroughly exposed to the Chironomus larvae but not to the fish larvae, as fish larvae were added in the food of mosquitofish only occasionally. In nature, Chironomus larvae are commonly located at the bottom of a waterbody during the day but they migrate upwards at night and are not readily encountered by visual predators such as mosquitofish.

The laboratory experiments in this study clearly indicated a strong influence of mosquitofish on commercially important carp species. The results of a multispecies prey choice test further supported this observation. Even in the presence of eight alternative prey types, the mosquitofish showed a strong preference for carp larvae. In the yolk-sac stage, carp larvae are slightly buoyant with less ability to avoid predation, 
which makes them more vulnerable to mosquitofish predation. Mosquitofish, being voracious feeders, may also have adversely affected carp larvae by eliminating their food from the environment (Arthington 1991, Bøhn and Amundsen 2001). Since vulnerability to predation in many species is size-selective (Paradis et al. 1996), larvae that are larger at hatching or reach a large size more quickly face a lower predation risk. However, continued food deprivation, leading to irreversible starvation effects in carp larvae could act indirectly by increasing predation risk (Rice et al. 1987). This is because weaker fish larvae take longer to grow out of the 'size bottleneck' of high predation susceptibility (Werner et al. 1983, Bøhn and Amundsen 2001). Mosquitofish, and especially G. affinis, were introduced worldwide to control mosquito populations. However, mosquitofish have a 'voracious' appetite and feed at rates much higher than most other similar-sized fish (Meffe and Snelson 1989).

Mosquitofish are not very efficient in preying on mosquito larvae in winter $\left(<20{ }^{\circ} \mathrm{C}\right)$. Sexual dimorphism and size differences play important roles in mosquitofish feeding behaviour, with multiple effects on the food web (Cabral et al. 1998, Specziár 2004). Previous studies have also reported gender-specific differences in the extent of carnivory and efficiency of utilising carp larval prey (Cabral and Marques 1999, Specziár 2004).

The single species test with predator (control agent) does not accrue same results in nature because of the presence of vast arrays of prey species. Therefore removals of target populations' depend on dietary niche breadth and preferences of the biocontrol agent. In the present study, environmentally relevant organisms were chosen and realistic concentrations were tested in our experimental set-up. The prey combinations used in the experiment are frequently occurring in natural mosquito breeding habitats and Gambusia are introduced for mosquito control. So, the laboratory results of our study can immediately be translated to the field. The mosquitofish form schools that may contain hundreds of fish. The schooling behaviour of mosquitofish leaves predation-free patches. Hence, predation risks may vary locally, depending on overall predator densities and the location of schools (Werner et al. 1983). Female carp could avoid mosquitofish at several spatial scales. Adult carp could use the strength of fish chemicals and exudates to identify areas in ponds where dense mosquitofish schools are present (Griswold and Lounibos 2005) and avoid these areas in selecting their breeding sites. In addition to seasonal and between-site variations, mosquitofish show an ontogenetic diet shift from diatoms, crustacean nauplii and microcrustaceans (particularly cladocerans) to larger prey, such as adult nematocerans (Mansfield and McArdle 1998, García-Berthou 1999). These attributes should be taken into account when extrapolating these laboratory results to natural conditions. In nature, mosquitofish decimate the larvae of their native counterparts not only directly, by predation, but also indirectly, through competition for food (Bence 1988, Arthington 1991, Bøhn and Amundsen 2001, Blaustein and Chase 2007, Leprieur et al. 2009).

The results of this study confirm the previous observations of opportunistic feeding in mosquitofish. The positive selection of fish larvae (when present in higher proportion) against all eight invertebrate prey types suggests heavy predation pressure on carp larvae in a natural setting. This particularly holds for the breeding season, when the relative abundance of fish larvae increases sharply.

\section{Conclusions}

Due to their higher dispersal tendency, invasiveness and adverse effects on native aquatic communities, the database of the IUCN Invasive Species Specialist Group classifies mosquitofish, along with eight other species, as among the world's 100 worst invasive species. Several studies have demonstrated the competitive advantage of mosquitofish over small indigenous fishes and amphibians. Their selective predation might have a significant effect on the structure and dynamics of freshwater ecosystems, as the less-preferred prey populations get an environment free of competition.

In order to understand the mechanisms of mosquitofish impact on native fish communities, it will be important to determine the preference of mosquitofish for the larvae of native fish species in relation to other naturally occurring prey. We observed a switch in preferences in relation to the relative abundance of a particular prey type suggesting that mosquitofish use an adaptive feeding strategy to maximise their fitness in an environment where prey are scarce. The selectivity experiments in this study indicate that mosquitofish positively selected fish larvae in all prey combinations tested. These results suggest that mosquito larvae are not the preferred food of mosquitofish when fish larvae are present in the natural habitat. Since mosquitofish and carp larvae have overlapping natural habitats, mosquitofish predation and prey preferences should have a consequence on regulatory management practices in conservation management and aquaculture.

Our results particularly suggest caution in the introduction of mosquitofish as biocontrol agents of mosquitoes in natural waters where carp are important in aquaculture, especially in South Asia. Although it is a threat to indigenous biodiversity and fails to control mosquitoes effectively, stocking and distribution of mosquitofish are still being practiced and encouraged by governmental and nongovernmental disease-vector control agencies in several countries. 


\section{Competing interests}

The authors declare that they have no competing interests.

\section{Authors' contributions}

RK made the conception and design of the experiment and analysis of data. PM was acquiring the data and provided some interpretation of the data. JS was involved in experiment with fish larvae. H-UD was revising the manuscript critically for important intellectual content and added substantially to the 'Introduction' and 'Discussion'. J-SH contributed to the 'Discussion' and gave final approval of the version to be published. All authors read and approved the final manuscript.

\section{Acknowledgements}

The Indian Council of Medical Research (ICMR, India) is acknowledged for sanctioning a research project (Evaluation of the potential of copepods to control disease vectors; Project No. ICMR-5/8-7 (179)/2004-ECD-II). and Acharya Narendra Dev College, University of Delhi, India, is acknowledged for providing facilities and support to RK. The Ministry of Science and Technology of Taiwan is thanked for a post-doctoral fellowship (NSC 98-2811-B-019-002) to RK and research funding to JSH (NSC 102-2923-B-019-001-MY3, MOST 1042611-M-019-004 and Most 104-2621-M-019-002). and research funding to TH SHIH (MOST 104-2621-M-019-002 and MOST 104-2621-M-037-001). This work was supported by a grant of KMU (KMU-Q104018/104.01.01-104.12.31). We thank Prof. T. R. Rao for stimulating discussions and suggestions. We also appreciate the assistance of Dr. Poonam for support at various stages of data analyses and manuscript preparation.

\section{Author details}

${ }^{1}$ Ecosystem Research Laboratory, Department of Zoology, Acharya Narendra Dev College (University of Delhi), Govindpuri, Kalkaji, New Delhi 110019 , India. ${ }^{2}$ Institute of Marine Biology, National Taiwan Ocean University, 2 Pei Ning Road, Keelung 202, Taiwan. ${ }^{3}$ Centre for Environmental Sciences, School of Earth Biological and Environmental Sciences, Central University of Bihar, Patna, India. ${ }^{4}$ Australian Rivers Institute, Griffith University, Nathan, QLD 4111, Australia. ${ }^{5}$ Department of Biomedical Science and Environmental Biology, KMU - Kaohsiung Medical University, No. 100, Shin-Chuan 1st Road, Kaohsiung 80708, Taiwan. ${ }^{6}$ Department of Biotechnology, Delhi Technological University, Delhi 110042, India.

\section{Received: 7 January 2015 Accepted: 16 July 2015}

Published online: 30 July 2015

\section{References}

Akre BG, Johnson DM (1979) Switching and sigmoid functional response curves by damsel fly naiads with alternative prey available. J Anim Ecol 48:703-720

Alcaraz C, Bisazza A, García-Berthou E (2008) Salinity mediates the competitive interactions between invasive mosquitofish and an endangered fish. Oecologia 155:205-213

Arthington AH (1991) Ecological and genetic impacts of introduced and translocated freshwater fishes in Australia. Can J Fish Aquat Sci 48(Suppl 1):33-43

Arthington AH, Marshall CJ (1999) Diet of the exotic mosquitofish, Gambusia holbrooki, in an Australian lake and potential for competition with indigenous fish species. Asian Fisheries Society 12:1-16

Barrier RFG, Hicks BJ (1994) Behavioral interactions between black mudfish (Neochanna diversus) and mosquitofish (Gambusia affinis Baird and Girard 1854). Ecol Freshw Fish 3:93-99

Bence JR (1988) Indirect effects and biological control of mosquitoes by mosquitofish. J Appl Ecol 25:505-521

Bence JR, Murdoch WW (1986) Prey size selection by the mosquitofish: relation to optimal diet theory. Ecology 67:324-336

Benejam L, Alcaraz C, Sasal P, Levert GS, García-Berthou E (2009) Life history and parasites of the invasive mosquitofish (Gambusia holbrooki) along a latitudinal gradient. Biol Invasions 11:2265-2277

Blaustein L, Chase JM (2007) Interactions between mosquito larvae and species that share the same trophic level. Annu Rev Entomol 52:489-507

Bøhn T, Amundsen PA (2001) The competitive edge of an invading species. Ecology 82:2150-2163

Cabral JA, Marques JC (1999) Life history, population dynamics and production of eastern mosquitofish, Gambusia holbrooki (Pisces, Poeciliidae), in rice fields of the lower Mondego River Valley, western Portugal. Acta Oecologia 20:607-620

Cabral JA, Mieiro CL, Marques JC (1998) Environmental and biological factors influence the relationship between a predator fish, Gambusia holbrooki, and its main prey in rice fields of the Lower Mondego River Valley (Portugal). Hydrobiologia 382:41-51

Chesson J (1983) The estimation and analysis of preference and its relationship to foraging models. Ecology 64:1297-1304

Chullasorn S, Yang W-X, Dahms H-U, Kangtia P, Holinska M, Anansatitporn W, Sanoamuang LO, Hwang J-S (2009) Naupliar development of Eucyclops cf. serrulatus tropicalis, Euc. cf. spatulatus, and Ectocyclops medius Kiefer, 1930 (Copepoda: Cyclopidae). Zool Stud 48(1):12-32

Clavero M, García-Berthou E (2005) Invasive species are a leading cause of animal extinctions. Trends Ecol Evol 20:110-110

Courtenay WR Jr, Maffe GK (1989) Small fishes in strange places: a review of introduced poecilliids. In: Meffe GK, Snelson FF Jr (eds) Ecology and evolution of livebearing fishes (Poeciliidae). Prentice Hall, Englewood Cliffs, New Jersey, pp 319-331

Crivelli AJ, Boy V (1987) The diet of mosquito fish, Gambusia affinis (Baird and Girard) (Poeciliidae) in Mediterranean France. Revue d'Ecologie 42:421-435

Crowl TA, Townsend CR, Mclntosh AR (1992) The impact of introduced brown and rainbow trout on native fish: the case of Australasia. Rev Fish Biol Fish 2:217-241

Dahms H-U (2004) Copepoda; Cyclopoida - Genera Mesocyclops and Thermocyclops by Ueda \& J. Reid (eds.) Book Review. Hydrobiologia 515:248-249

Dahms H-U (2005) Aquatic ecology of rice fields. C.H. Fernando, F. Goeltenboth and J. Margraf, editors (Volumes Publishing, Kitchener, Ontario, Canada, N2B2B9, A third millenium book 205, first edition, Limnology 6:137-138, book review

Dahms H-U, Dobretsov S, Lee J-S (2011a) Effects of UV radiation on marine ectotherms in polar regions. Comp Biochem Physiol C 153:363-371

Dahms H-U, Hagiwara A, Lee J-S (2011b) Ecotoxicology, ecophysiology, and mechanistic studies with rotifers. Aquat Toxicol 101:1-12

Duryea R, Donnelly J, Guthrie D, O'Malley C, Romanowski M, Schmidt R (1996) Gambusia affinis effectiveness in New Jersey mosquito control. In: Proceedings of the Eighty-Third Annual Meeting of the New Jersey Mosquito Control Association, Inc., pp 95-102

Englund RE (1999) The impacts of introduced Poeciliid fish and Odonata on the endemic Megalagrion (Odonata) damselflies of Oahu Island, Hawaii. J Insect Conserv 3:225-243

Garcia-Berthou E (1999) Food of introduced mosquito fish: ontogenetic diet shift and prey selection. J Fish Biol 55:135-147

Gilbert JJ, Williamson CE (1978) Predator-prey behaviour and its effect on rotifer survival in associations of Mesocyclops edax, Asplanchna girodi, Polyarthra vulgaris and Keratella cochlearis. Oecologia 37:13-22

Gill J (2001) Generalized linear models: a unified approach. Sage University Paper Series on Quantitative Applications in the Social Sciences No. 134. Sage, Thousand Oaks, CA, USA

Gooden B, French K, Turner PJ, Downey PO (2009) Impact threshold for an alien plant invader, Lantana camara L., on native plant communities. Biol Conserv 142:2631-2641

Goodsell JA, Kats LB (1999) Effect of introduced mosquitofish on Pacific tree frogs and the role of alternative prey. Conserv Biol 13:921-924

Gophen M, Yehuda Y, Malinkov A, Degani G (1998) Food composition of the fish community in Lake Agmon. Hydrobiologia 380:49-57

Gotelli NJ, Ellison AM (2004) A primer of ecological statistics. Sinauer Associates, Sunderland

Griswold MW, Lounibos LP (2005) Does differential predation permit invasive and native mosquito larvae to coexist in Florida? Ecol Entomol 30:122-127

Hamer AJ, Lane SJ, Mahony MJ (2002) The role of introduced mosquitofish (Gambusia affinis) in excluding the native green and golden bell frog (Litoria aurea) from original habitats in south-eastern Australia. Oecologia 132:445-452

Hazelton PD, Grossman GD (2009) The effects of turbidity and an invasive species on foraging success of rosyside dace (Clinostomus funduloides). Freshw Biol 54:1977-1989

Helfman GS (2007) Fish Conservation: a guide to understanding and restoring global aquatic biodiversity and fishery resources. Publishers Island Press, 1718, Washington, DC

Helfman GS, Collette BB, Facey DE, Bowen BW (2009) The diversity of fishes: biology, evolution, and ecology. Second edition. Wiley-Blackwell 
Howe E, Howe C, Lim R, Burchett M (1997) Impact of the introduced poeciliid Gambusia holbrooki (Girard, 1859) on the growth and reproduction of Pseudomugil signifer (Kner, 1865) in Australia. Mar Freshw Res 48:425-434

Hurlbert SH, Mulla MS (1981) Impacts of mosquitofish (Gambusia affinis) predation on plankton communities. Hydrobiologia 83:125-151

Hurlbert SH, Zedler J, Fairbanks D (1972) Ecosystem alteration by mosquitofish (Gambusia affinis) predation. Science 175:639-641

Hwang D-S, Dahms H-U, Park HG, Lee J-S (2013) A new intertidal Brachionus and intrageneric phylogenetic relationships among Brachionus as revealed by allometry and CO1-ITS1 gene analysis. Zool Stud 52(13):1-10

ISSG (2000) 100 of the world's worst invasive species database. Invasive Species Specialist Group. University of Auckland, Auckland

Ivantsoff WA (1999) Detection of predation on Australian native fishes by Gambusia holbrooki. Mar Freshw Res 50:467-468

lyer N, Rao TR (1996) Responses of the predatory Asplanchna intermedia to prey species differing in vulnerability: laboratory and field studies. Freshw Biol 36:521-533

Jhingran VG (1991) Fish and fisheries of India. $3^{\text {rd }}$ edition. Hindustan Publishing Corporation, Delhi, India, XIV +645pp

Kak A (1999) Field and laboratory studies on interaction between rotifers and cladocerans. Ph.D Thesis, University of Delh

Kanji GK (2011) 100 Statistical tests, 3rd edn. Sage publications, New Dehi, 242

Kennard MJ, Arthington AH, Pusey BJ, Harch BD (2005) Are alien fish a reliable indicator of river health? Freshw Biol 50:174-193. doi:10.1111/J.1365[--]2427.2004.01293.X

Kim J-H, Jeon HJ, Baek JM, Han KN, Dahms H-U (2013a) EDCs-induced glucocorticoid receptor related genes expression of the river pufferfish, Takifugu obscurus. Aquac Res 44:985-994

Kim J-H, Jung SJ, Lee W-O, Dahms H-U, Han K-N (2013b) Osmoregulation related gene expression of the anadromous river pufferfish Takifugu obscurus under sudden salinity changes. J Fish Physiol Biochem. [doi:10.1007/s10695-013-9837-z] ONLINE 02August2013

Kiørboe T, Saiz E, Viitasalo M (1996) Prey switching behaviour in the planktonic copepod Acartia tonsa. Mar Ecol Prog Ser 143:65-75

Komak S, Crossland MR (2000) An assessment of the introduced mosquitofish (Gambusia affinis holbrooki) as a predator of eggs, hatchlings and tadpoles of native and non-native anurans. Wildl Res 27:185-189

Krebs JR, Kacelnik A (1991) Decision making. In: Krebs JR, Davis NB (eds) Behavioral ecology, an evolutionary approach. Blackwell Scientific Publications, London, pp 105-136

Kumar R (2003) Effects of Mesocyclops thermocyclopoides (Copepoda: Cyclopoida) predation on the population growth patterns of different prey species. J Freshw Ecol 18:384-393

Kumar R, Rao TR (2003) Predation on mosquito (Anopheles stephensi and Culex quinquefasciatus) larvae by Mesocyclops thermocyclopoides (Copepoda; Cyclopoida) in the presence of alternate prey. Int Rev Hydrobiol 88:570-581

Kumar R, Dahms H-U, Muhid P, Tseng L-C, Hwang J-S (2008) Potential of three aquatic predators to control mosquitoes in the presence of alternative prey: a comparative experimental assessment. Mar Freshw Res 59:817-835

Kumar R, Souissi S, Hwang J-S (2012) Vulnerability of carp larvae to copepod predation as a function of larval age and body length. Aquaculture 338-341:274-283

Lancaster HF, Drenner RW (1990) Experimental mesocosm study of the separate and interactive effects of phosphorous and mosquitofish (Gambusia affinis) on plankton community structure. Can J Fish Aquat Sci 47:471-479

Landry MR (1981) Switching between herbivory and carnivory by the planktonic marine copepod Calanus pacificus. Mar Biol 65:77-82

Lee CH, Dahms H-U, Cheng SH, Souissi S, Schmitt FG, Kumar R, Hwang J-S (2010) Predation of Pseudodiaptomus annandalei (Copepoda: Calanoida) by the grouper fish fry Epinephelus coioides under different hydrodynamic conditions. J Exp Mar Biol Ecol 393:17-22

Leprieur F, Brosse S, García-Berthou E, Oberdorff T, Olden JD, Townsend CR (2009) Scientific uncertainty and the assessment of risks posed by non-native freshwater fishes. Fish Fish 10:88-97

Lever C (1996) Naturalized fishes of the world. Academic Press, London

Leyse KE, Lawler SP, Strange T (2004) Effects of an alien fish, Gambusia affinis, on an endemic California fairy shrimp, Linderiella occidentalis: implications for conservation of diversity in fishless waters. Biol Conserv 118:57-65

Linden AL, Cech JJ (1990) Prey selection by mosquitofish (Gambusia affinis) in California rice fields: effect of vegetation and prey species. J Am Mosq Control Assoc 6:115-120
Lowe S, Browne N, Boudjelas S (2000) 100 of the world's worst invasive alien species-a selection from the Global Invasive Species Database. Invasive Species Specialist Group, World Conservation Union

Lubzens E, Tandler A, Minkoff G (1989) Rotifers as food in aquaculture. Hydrobiologia 186(187):387-400

Macdonald JI, Tonkin ZD, Ramsey DS, Kaus AK, King AK, Crook DA (2012) Do invasive eastern gambusia (Gambusia holbrooki) shape wetland fish assemblage structure in South-eastern Australia? Mar Freshw Res 63:659-671

Manly BFJ (1974) A model for certain types of selection experiments. Biometrics 30:281-294

Mann HB, Whitney DR (1947) On a test of whether one or two random variables is stochastically larger than the other. Ann Math Stat 18:50-60

Mansfield S, McArdle BH (1998) Dietary composition of Gambusia affinis (Family: Poeciliidae) populations in the northern Waikato region of New Zealand. N Z J Mar Freshw Res 32:375-383

Marchetti MP, Moyle PB (2001) Keeping alien fishes at bay: effects of flow regime and habitat structure on fish assemblages in a regulated California stream. Ecol Appl 11:75-87

Margaritora FG (1990) Influence of Gambusia affinis on the features and dynamics of the zooplankton community in the pools of Castel Porziano (Latium). Riv Idrobiol 29:747-762

Matsumura-Tundisi T, Rietzler AC, Espindola ELG, Tundisi JG, Rocha O (1990) Predation on Ceriodaphnia cornuta and Brachionus calyciflorus by two Mesocyclops species coexisting in Barra Bonita reservoir (SP, Brazil). Hydrobiologia 198:141-151

Meffe GK, Snelson FF (1989) An ecological overview of poeciliid fishes. In: Meffe GK, Snelson FF (eds) Ecology and evolution of livebearing fishes (Poeciliidae). Prentice Hall, Upper Saddle River, New Jersey, pp 13-31

Mookerji N, Rao TR (1993) Patterns of prey selection in rohu (Labeo rohita) and singhi (Heteropneustes fossilis) larvae under light and dark conditions. Aquaculture 118:85-104

Mookerji N, Rao TR (1994) Influence of ontogenetic changes in prey selection on the survival and growth of rohu, Labeo rohita and singhi, Heteropneustes fossilis larvae. J Fish Biol 44:479-490

Nagdali SS, Gupta PK (2002) Impact of mass mortality of a mosquito fish, Gambusia affinis on the ecology of a freshwater eutrophic lake (Lake Nainital, India). Hydrobiologia 468:45-52

Oaten A, Murdoch WW (1975) Predator switching, functional response, and stability. Am Nat 109:299-318

Olden JD, Kennard MJ, Leprieur F, Tedesco PA, Winemiller KO, García-Berthou E (2010) Conservation biogeography of freshwater fishes: recent progress and future challenges. Divers Distrib 16:496-513

Paradis AR, Pepin P, Brown JA (1996) Vulnerability of fish eggs and larvae to predation: review of the influence of the relative size of prey and predator. Can J Fish Aquat Sci 53:1226-1235

Peck GW, Walton WE (2008) Effect of mosquitofish (Gambusia affinis) and sestonic food abundance on the invertebrate community within a constructed treatment wetland. Freshw Biol 53:2220-2233

Pyke GH (1984) Optimal foraging theory: a critical review. Annu Rev Ecol Syst 15:523-575

Rao TR (2003) Ecological and ethological perspectives in larval fish feeding. J Appl Aquac 13:145-178

Rao TR, Kumar R (2002) Patterns of prey selectivity in the cyclopoid copepod Mesocyclops thermocyclopoides. Aquat Ecol 36:411-424

Rehage JS, Sih A (2004) Dispersal behavior, boldness, and the link to invasiveness: a comparison of four Gambusia species. Biol Invasions 6:379-391

Rehage JS, Barnett BK, Sih A (2005) Foraging behaviour and invasiveness: do invasive Gambusia exhibit higher feeding rates and broader diets than their noninvasive relatives? Ecol Freshw Fish 14:352-360

Rice JA, Crowder LB, Binkowski FP (1987) Evaluating potential sources of mortality for larval bloater (Coregonus hoyi): Starvation and vulnerability to predation. Can J Fish Aquat Sci 44:467-472

Scheiner SM (2001) MANOVA: multiple response variables and multispecies interactions. In: Scheiner SM, Gurevitch J (eds) Design and analysis of ecological experiments, 2nd edn. Oxford University Press, Oxford, UK, pp 99-115

Schoener TW (1987) A brief history of optimal foraging theory. In: Kamil AC, Krebs JR, Pulliam HR (eds) Foraging behavior. Plenum Press, New York, pp 5-67

Smith GR, Terlecky AJ, Dayer CB, Boyd A, Ogle ME, Dibble CJ (2011) Effects of mosquitofish and ammonium nitrate on activity of green frog (Lithobates clamitans) tadpoles: a mesocosm experiment. J Freshw Ecol 26:59-63 
Sokal RR, Rohlf FJ (2012) Biometry: the principles and practice of statistics in biological research, 4th edn. W. H. Freeman and Co., New York, 937 pp

Sornsupharp B, Lomthaisong K, Dahms HU, Sanoamuang L (2013a) Effects of dried fairy shrimp Streptocephalus sirindhornae meal on pigmentation and carotenoid deposition in flowerhorn cichlid; Amphilophus citrinellus (Günther, 1864) X Cichlasoma trimaculatum (Günther, 1867). Aquaculture Research: 1-12

Sornsupharp S, Dahms H-U, Sanoamuang L (2013b) Nutrient composition of fairy shrimp Streptocephalus sirindhornae nauplii as live food and growth performance of giant freshwater prawn postlarvae. Aquac Nutr 19:349-359

Specziár A (2004) Life history pattern and feeding ecology of the introduced eastern mosquito fish, Gambusia holbrooki in a thermal spa under temperate climate of Lake Hévíz, Hungary. Hydrobiologia 522:249-260

Swanson C, Cech JJJ, Pietrahita RH (1996) Mosquitofish, biology, culture and use in mosquito control. Mosquito and Vector Control Association of California and University of California, Sacramento, CA

Tseng L-C, Kumar R, Dahms H-U, Chen Q-C, Hwang J-S (2008) Copepod gut contents, ingestion rates and feeding impact in relation to their size structure in the southeastern Taiwan Strait. Zool Stud 47(4):402-416

Vargas MJ, de Sostoa A (1996) Life history of Gambusia holbrooki (Pisces: Poeciliidae) in the Ebro Delta (NE Iberian Peninsula). Hydrobiologia 341:215-224

Vidal O, García-Berthou E, Tedesco PA, García-Marín L (2010) Origin and genetic diversity of mosquitofish (Gambusia holbrooki) introduced to Europe. Biol Invasions 12:841-851

Webb C, Joss J (1997) Does predation by the fish Gambusia holbrook (Atheriniformes: Poeciliidae) contribute to declining frog populations? Aust Zool 30:316-326

Werner EE, Hall DJ (1974) Optimal foraging and the size selection of prey by the bluegill sunfish (Lepomis macrochirus). Ecology 55:1042-1052

Werner EE, Gilliam JF, Hall DJ, Mittelbach GG (1983) An experimental test of the effects of predation risk on habitat use in fish. Ecology 64:1540-1548

Williamson CE (1983) Behavioural interaction between a cyclopoid predator and its prey. J Plankton Res 5:701-711

Wurtsbaugh W, Cech JJ, Compton J (1980) Effect of fish size on prey size selection in Gambusia affinis. In: Proceedings and Papers of the Forty-eighth Annual Conference of the California Mosquito and Vector Control Association., pp 48-51

\section{Submit your manuscript to a SpringerOpen ${ }^{\circ}$ journal and benefit from:}

- Convenient online submission

- Rigorous peer review

- Immediate publication on acceptance

- Open access: articles freely available online

- High visibility within the field

- Retaining the copyright to your article

Submit your next manuscript at $>$ springeropen.com 